Vol.05, No.01, April 2019

Doi: $10.24198 /$ cosmogov.v2i2.xxxxx

\title{
STRATEGI SOSIALISASI POLITIK DALAM PENINGKATAN PARTISIPASI PEMILIH PEREMPUAN PADA PILKADA SERENTAK DI KOTA MAGELANG
}

\author{
Eko Ari Wibowo ${ }^{1}$ \\ Muradi $^{2}$ \\ Arfin Sudirman ${ }^{3}$ \\ ${ }^{1}$ Pascasarjana Ilmu Politik, Fakultas Ilmu Sosial dan Ilmu Politik, Universitas \\ Padjadjaran \\ ${ }^{2}$ Pascasarjana Ilmu Politik, Fakultas Ilmu Sosial dan Ilmu Politik, Universitas \\ Padjadjaran \\ ${ }^{3}$ Pascasarjana Ilmu Politik, Fakultas Ilmu Sosial dan Ilmu Politik, Universitas \\ Padjadjaran \\ Email: eko_ari@yahoo.com

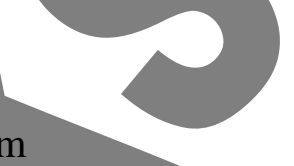 \\ Pemilih perempuan menjadi salah satu segmen pemilih strategis dalam sosialisasi \\ politik yang dilaksanakan oleh KPU Kota Magelang karena selain populasinya \\ yang melebihi pemilih laki-laki, juga karena adanya hambatan bagi perempuan \\ dalam hal pendidikan, ekonomi, dan sosial yang menyebabkan perempuan lebih \\ banyak berada dalam wilayah domestik serta terbatasnya akses informasi \\ termasuk tentang kepemiluan. Pada penyelenggaraan Pilkada serentak tahun 2015, \\ KPU menetapkan target tingkat partisipasi pemilih secara nasional sebesar 77,5\%. \\ Sebagai upaya mencapai target tersebut KPU Kota Magelang menerapkan strategi \\ dalam melaksanakan sosialisasi politik kepada pemilih perempuan. Metode \\ kualitatif digunakan pada penelitian ini, dan teknik pengumpulan data yang \\ digunakan melalui wawancara dan dokumentasi. Penentuan informan dilakukan \\ dengan purposeful menggunakan strategi snowball. Hasil dan pembahasan \\ mengungkapkan bahwa KPU Kota Magelang menerapkan strategi ofensif dan \\ defensif secara bersamaan namun dengan kelompok target pemilih perempuan \\ yang berbeda. Penentuan kelompok target pemilih perempuan efektif dilakukan \\ melalui pendekatan formal, informal, dan melalui media massa. Penerapan \\ strategi ofensif lebih mendominasi dalam peningkatan partisipasi pemilih \\ perempuan pada Pilkada Kota Magelang tahun 2015.
}

Kata kunci : strategi; sosialisasi politik; pilkada; perempuan

\begin{abstract}
Women voters became one of the strategic voters segments in political socialization conducted by the Election Commission of Magelang City because in addition to the population that exceeded male voters, it was also because of the
\end{abstract}


Vol.05, No.01, April 2019

Doi: $10.24198 /$ cosmogov.v2i2.xxxxx

obstacles for women in education, economy and social that caused more women to be in domestic area as well as limited access to information including about elections. In the implementation of the elections in conjunction in 2015, the Election Commission set a target of national voter turnout rate of $77.5 \%$. In an effort to reach the target, the Election Commission of Magelang City implemented a strategy to implement political socialization to women voters. Qualitative methods are used in this study, and data collection techniques used through interviews and documentation. Determination of informants conducted with purposeful using snowball strategy. The results and discussions reveal that the Election Commission of Magelang City is implementing an offensive and defensive strategy simultaneously but with different target groups of women voters. The determination of effective women voter target groups is done through formal, informal, and mass media approaches. The implementation of offensive strategy is more dominant in increasing the participation of women voters in Election of Magelang City in 2015.

Keywords: strategy; political socialization; local elections; woman

\section{PENDAHULUAN}

Pemilihan Umum (Pemilu) merupakan sarana perwujudan kedaulatan rakyat menghasilkan pemerintahan yang demokratis. Pemilihán Kepala Daerah (Pilkada) masuk ke dalam rezim Pemilu sejak berlakunya Undang-Undang Nomor 32 Tahun 2004 tentang Pemerintahan Daerah, dimana Kepala Daerah dipilih secara langsung oleh rakyat. KPU Kota Magelang sebagai penyelenggara Pilkada Kota Magelang merupakan badan penyelenggara Pemilu sebagaimana diamanatkan oleh Undang-Undang Nomor 15 Tahun 2011 tentang Penyelenggara Pemilu, yang diberikan tugas dan wewenang untuk menyelenggarakan seluruh tahapan Pilkada. Salah satu tugas dan wewenang KPU Kota Magelang dalam penyelenggaraan Pilkada adalah melaksanakan sosialisasi politik.
Kota Magelang merupakan salah satu daerah yang ikut dalam pelaksanaan Pilkada serentak pertama di Indonesia tahun 2015 bersama dengan 268 daerah lainnya. Berdasarkan data KPU Kota Magelang, jumlah daftar pemilih tetap (DPT) sebanyak 89.112 pemilih, yang terdiri dari 42.490 pemilih laki-laki dan 46.622 pemilih perempuan. Artinya jumlah pemilih perempuan di Kota Magelang lebih banyak dari pemilih laki-laki dengan prosentase cukup signifikan yaitu sebesar 52,32\%, yang melebihi ratarata prosentase pemilih perempuan secara nasional pada Pilkada serentak tahun 2015 sebesar 50,10\% (KPU, 2016). Berdasarkan data rekapitulasi perolehan suara Pilkada Kota Magelang tahun 2015 menunjukkan bahwa pencapaian tingkat partisipasi pemilih perempuan dalam menggunakan hak pilihnya di tempat pemungutan suara 
Vol.05, No.01, April 2019

Doi: 10.24198/cosmogov.v2i2.xxxxx

(TPS) pada hari pemungutan suara tanggal 9 Desember 2015 sebesar $77,10 \%$, sedangkan tingkat partisipasi pemilih laki-laki sebesar $73,17 \%$. Jika dibandingkan dengan hasil Pilkada pada periode sebelumnya tahun 2010 maka tingkat partisipasi perempuan di Kota Magelang mengalami kenaikan, dimana tingkat partisipasi pemilih perempuan pada Pilkada tahun 2010 sebesar $73,70 \%$ dan pemilih laki-laki sebesar $69,60 \%$. Meskipun demikian, pencapaian tingkat partisipasi pemilih perempuan di Kota Magelang pada Pilkada Tahun 2015 masih belum bisa mencapai target partisipasi pemilih nasional sebagaimana telah ditetapkan oleh KPU sebesar 77,5\% yang dituangkan dalam rencana strategis KPU. Padahal jika dilihat dari kondisi geografisnya, Kota Magelang relatif tidak ada hambatan bagi pemilih untuk hadir dan menggunakan hak pilihnya ke Tempat Pemungutan Suara (TPS), karena luas wilayahnya hanya sekitar $18,12 \mathrm{~km}^{2}$ yang terdiri dari 3 Kecamatan, sehingga jarak tempuh menuju ke TPS untuk menggunakan hak pilihnya relatif dekat. Kemudian secara topografis akses jalan di Kota Magelang juga relatif mudah untuk dilalui oleh pemilih untuk menuju ke TPS, karena wilayahnya berupa dataran dengan kemiringan berkisar antara $5^{\circ}$ - $45^{\circ}$ dan berada pada ketinggian 380 $\mathrm{m}$ di atas permukaan laut, sehingga termasuk daerah yang cukup rata dan bebas banjir (BPS Kota Magelang, 2015: 2).

Jaringan Pendidikan Pemilih untuk Rakyat (JPPR) menilai bahwa ada tiga faktor utama yang menyebabkan rendahnya partisipasi pemilih dalam Pilkada, yaitu terbatasnya pilihan pasangan calon dari yang diajukan partai politik, perbedaan antara janji kampanye dengan realitas politik, dan turunnya aktivitas sosialisasi dan pendidikan pemilih oleh penyelenggara Pemilu (KPU, 2017: 314). Dari seluruh faktor penyebab rendahnya partisipasi pemilih tersebut sebenarnya menjadi tanggung jawab bersama seluruh pemangku kepentingan (stakeholders) Pemilu, namun karena Undang-Undang Nomor 15 Tahun 2011 tentang Penyelenggara Pemilu memberikan kewajiban dan kewenangan kepada penyelenggara Pemilu untuk memberikan sosialisasi dan pendidikan politik kepada pemilih maupun peserta Pemilu, maka agenda sosialisasi politik tersebut harus diselenggarakan oleh KPU beserta jajarannya. Besarnya partisipasi perempuan dalam Pemilu dapat dipengaruhi oleh kebijakan dan program yang dijalankan oleh penyelenggara Pemilu. Oleh karena itu, sangatlah penting bahwa penyelenggara Pemilu secara sadar dan proaktif mengikutsertakan gender ke dalam analisis, perencanaan, dan implementasi seluruh kegiatannya dan juga 
Vol.05, No.01, April 2019

Doi: 10.24198/cosmogov.v2i2.xxxxx

interaksi dengan pemangku kepentingan lain yang terlibat dalam proses kepemiluan (Bibler, Mohan, \& Ryan, 2014: 3)

Adanya fenomena jumlah pemilih perempuan yang lebih banyak dibandingkan dengan pemilih laki-laki di Kota Magelang, namun tingkat partisipasi pemilih perempuan di Kota Magelang pada Pilkada tahun 2015 tetap tidak bisa mencapai target sebagaimana telah dipaparkan di atas, maka peneliti tertarik untuk melakukan penelitian tentang strategi sosialisasi politik yang dilaksanakan oleh KPU Kota Magelang dalam upaya peningkatan partisipasi pemilih perempuan pada Pilkada tahun 2015. Penelitian tentang strategi politik oleh organisasi penyelenggara Pemilu dalam pelaksanaan sosialisasi politik untuk tujuan peningkatan partisipasi politik masih jarang dilakukan, sebagian besar penelitian terdahulu membahas strategi politik yang dipakai-untuk tujuan pemenangan dalam Pemilu oleh para kandidat, tim pemenangan atau partai politik.

\section{METODE PENELITIAN}

Penelitian ini menggunakan metode kualitatif, dipilih karena lebih menekankan pada kedalaman data dan penjelasan, dengan teknik pengumpulan data yang dilakukan melalui wawancara (interview) dan dokumentasi (documents). Sumber data berasal dari data primer melalui wawancara dan data sekunder berupa literatur-literatur dan dokumendokumen yang berkaitan dengan kegiatan sosialisasi politik. Dalam penelitian ini pengujian keabsahan data didasarkan pada derajat kebenaran dan kepercayaan data yang diperoleh, dan kesesuaian terhadap peraturan perundangan beserta dokumen resmi yang dikeluarkan instansi yang berwenang.

\section{HASIL DAN PEMBAHASAN}

1. Pentingnya Sosialisasi Politik Kepada Peunilih Perempuan Pemilih perempuan menjadi salah satu segmen pemilih strategis dalam sosialisasi politik yang dilaksanakan oleh KPU Kota Magelang karena selain populasinya yang banyak melebihi pemilih lakilaki, juga karena adanya hambatan bagi perempuan di Kota Magelang dalam hal pendidikan, ekonomi, dan sosial yang menyebabkan perempuan lebih banyak berada dalam wilayah domestik dan terbatasnya akses informasi termasuk tentang Pemilu. Hambatan pertama dalam bidang pendidikan yaitu, masih banyaknya perempuan di Kota Magelang yang tidak bisa membaca dan menulis. Perempuan berusia 10 tahun keatas yang tidak bisa membaca dan menulis jumlahnya lebih banyak dibandingkan dengan laki-laki yaitu mencapai $3,22 \%$ dari jumlah penduduk, sedangkan laki-laki hanya sebanyak 1,57\%. Hal tersebut disebabkan karena penduduk 
Vol.05, No.01, April 2019

Doi: 10.24198/cosmogov.v2i2.xxxxx

perempuan di Kota Magelang yang berusia 10 tahun keatas tidak bersekolah jumlahnya mencapai $4,07 \%$, sedangkan laki-laki yang tidak bersekolah hanya $0,70 \%$ dari jumlah penduduk (BPS Kota Magelang, 2015: 9). Rendahnya tingkat pendidikan, kemampuan membaca dan menulis mengakibatkan rendahnya pula pengetahuan serta pemahaman yang dimiliki sehingga pada akhirnya dapat menimbulkan rendahnya kesadaran sipil dan politik bagi perempuan di Kota Magelang.

Hambatan kedua berasal dari bidang ekonomi terkait dengan angkatan kerja atau kesempatan kerja. Jumlah perempuan di Kota Magelang yang bekerja, baik pada sektor jasa, pertanian, industri, konstruksi, perdagangan transportasi, keuangan dan lainnya hanya sejumlah $35,6 \%$ dari seluruh angkatan kerja sebesar 64.382 jiwa pada tahun 2014 (BPS Kota Magelang, 2015: 8). Artînya banyak perempuan di Kota Magelang yang tidak bekerja atau hanya mengurus rumah tangga, jadi kecenderungan perempuan berperan untuk mengasuh anak dan urusan rumah tangga, seringkali membuat perempuan hanya memiliki sedikit waktu untuk berkegiatan dalam sektor publik. Kemudian hambatan ketiga yang berasal dari faktor sosial, dimana banyak pemilih perempuan di Kota Magelang yang tinggal di lingkungan asrama TNI/Polri. Perempuan yang tinggal di lingkungan asrama tersebut pada umumnya memiliki kepala keluarga sebagai anggota TNI/Polri yang tidak memiliki hak politik. Jadi perempuan yang tinggal di lingkungan tersebut jarang mendapatkan informasi seputar politik, sehingga kurang tertarik dengan urusan politik. Perempuan di lingkungan asrama lebih banyak beraktifitas terkait urusan kedinasan dari suaminya. Selain hambatan dalam hal pendidikan, ekonomi, dan sosial sebagaimana diuraikan di atas, menurut Mar'iyah (2001) juga terdapat hambatan di bidang politik yang dialami oleh kaum perempuan, yaitu kurangnya sosialisasi politik yang khusus menyasar kaum perempuan dengan mengangkat isuisu tentang perempuan yang dilakukan oleh partai politik ataupun penyelenggara Pemilu.

Mengatasi berbagai hambatan yang dialami oleh pemilih perempuan di Kota Magelang dalam mengakses dan mendapatkan informasi tentang Pemilu dan tahapan Pilkada Kota Magelang, merupakan tantangan bagi KPU Kota Magelang dalam menjalankan agenda sosialisasi politik pada Pilkada Kota Magelang tahun 2015. Dibutuhkan pendekatan yang sesuai dengan karakteristik pemilih perempuan. Untuk itu sosialisasi politik yang dilakukan oleh KPU Kota Magelang kepada pemilih perempuan penting dilakukan, melalui kegiatan-kegiatan yang 
Vol.05, No.01, April 2019

Doi: 10.24198/cosmogov.v2i2.xxxxx

familier terhadap perempuan agar hambatan-hambatan bagi pemilih perempuan dalam memperoleh informasi kepemiluan dan tahapan Pilkada Kota Magelang tahun 2015 dapat teratasi.

\section{Penerapan Strategi Dalam Sosialisasi Politik}

Penggunaan strategi yang tepat merupakan salah satu hal penting yang harus dilakukan oleh KPU Kota Magelang dalam melaksanakan sosialisasi politik. Strategi sosialisasi politik dalam Pilkada digunakan untuk merealisasikan cita-cita politik yang mengarah kepada perubahan masyarakat ke arah yang lebih baik, seperti peningkatan pengetahuan, pemahaman dan kesadaran masyarakat tentang hak pilinnya dalam Pilkada. Agar dapat meningkatkan partisipasi pemilih dalam Pilkada Kota Magelang tahun 2015, maka dibutuhkan berbagai usaha, upaya dan tindakan yang dilakukan oleh KPU Kota Magelang sebagai penyelenggara Pemilu.

Penggunaan strategi yang tepat pada akhirnya akan mengerucut pada kegiatan-kegiatan yang lebih kongkrit, spesifik dan dapat diimplementasikan di lapangan. Tujuan utama dari strategi itu pada prinsipnya adalah pencapaian target Scroder (2010: 323). Pada penyelenggaraan Pilkada Tahun 2015 secara serentak, KPU telah menetapkan target prosentase tingkat partisipasi pemilih sebesar 77,5\% bagi 269 daerah di seluruh Indonesia sebagaimana tercantum dalam Rencana Strategis KPU Tahun 20152019. Keberhasilan terhadap pencapaian tujuan tersebut sangat ditentukan oleh kinerja KPU Kota Magelang sebagai aktor utama penyelenggara Pilkada dalam mensinergikan seluruh potensi yang ada, baik itu menyangkut sumber daya manusia, dana dan dukungan pemangku kepentingan dalam Pilkada. Keterpaduan dan keselarasan dalam mengelola semua elemen tersebut yang tertuang dalam strategi sosialisasi politik KPU Kota Magelang yang kemudian diimplementasikan dalam berbagai kegiatan, agar dapat meningkatkan pengetahuan, pemahaman dan kesadaran masyarakat dalam menggunakan hak pilihnya yang pada akhirnya dapat meningkatkan partisipasi pemilih dalam Pilkada Kota Magelang Tahun 2015.

$$
\text { Pada penyelenggaraan }
$$

Pilkada tahun 2010, KPU Kota Magelang dalam melakukan sosialisasi politik belum terfokus kepada kelompok pemilih perempuan meskipun jumlahnya melebihi setengah dari seluruh jumlah pemilih. Kemudian pada Pilkada tahun 2015 KPU Kota Magelang menetapkan pemilih perempuan sebagai salah satu segmen strategis dalam agenda sosialisasi politik. Banyaknya pemilih perempuan dapat menjadi 
Vol.05, No.01, April 2019

Doi: 10.24198/cosmogov.v2i2.xxxxx

peluang bagi KPU Kota Magelang untuk meningkatkan prosentase partisipasi pemilih pada Pilkada tahun 2015 dengan cara melakukan sosialisai politik terfokus pada segmen pemilih perempuan, dengan harapan bahwa pemilih perempuan dengan jumlah yang banyak akan mendorong peningkatan prosentase partisipasi pemilih secara signifikan. Namun, dengan banyaknya jumlah pemilih perempuan juga dapat menjadi ancaman, yaitu berupa penurunan prosentase partisipasi pemilih pada Pilkada tahun 2015 apabila pemilih perempuan tersebut banyak yang tidak menggunakan hak pilihnya dalam Pilkada. Untuk itu KPU Kota Magelang menerapkan strategi sosialisasi politik dalam upaya peningkatan partisipasi pemilih perempuan pada Pilkada tahun 2015.

\section{Pemetaan Kelompok Target} Pemilih Perempuan

KPU Kota Magelang dalam menerapkan strategi sosialisasi politik terlebih dahulu menentukan kelompok target agar dapat memetakan kelompok pemilih perempuan pada Pilkada Kota Magelang tahun 2015 secara spesifik. Dengan adanya pengelompokan pemilih perempuan tersebut akan mempermudah dalam menyusun program yang akan diimplementasikan dalam kegiatan sosialisasi politik. Program yang akan diimplementasikan dalam kegiatan sosialisasi politik tersebut harus disesuaikan dengan karakteristik dari kelompok target pemilih perempuan, agar informasi kepemiluan dan tahapan Pilkada Kota Magelang tahun 2015 dapat lebih mudah untuk diterima dan tepat sasaran. Kelompok pemilih perempuan tersebut diakses melalui empat pendekatan yaitu: pendekatan formal, pendekatan informal, pendekatan melalui media massa, dan pendekatan melalui media jaringan sebagaimana menurut Scroder (2010: 325).

a. Pendekatan Formal Pendekatan formal kepada pemilih perempuan di Kota Magelang dilakukan dengan kegiatan yang berkaitan dengan aktifitas organisasi perempuan tersebut. Untuk mendapatkan data organisasi perempuan yang ada di Kota Magelang maka KPU Kota Magelang berkoordinasi dengan Badan Kesatuan Bangsa, Politik dan Perlindungan Masyarakat (Badan Kesbangpolinmas) Kota Magelang, karena sesuai dengan peraturan perundang-undangan bahwa semua organisasi masyarakat harus terdaftar di Pemerintah Daerah melalui Badan Kesbangpolinmas. Data organisasi perempuan yang terdaftar di Kota Magelang terdiri dari: Gabungan Organisasi Wanita (GOW), Pembinaan Kesejahteraan 
Vol.05, No.01, April 2019

Doi: 10.24198/cosmogov.v2i2.xxxxx

Keluarga (PKK), Persatuan Istri Tentara (Persit) Kodim 0705, Bhayangkari Magelang Kota, Kaukus Perempuan Politik Cabang Kota Magelang, Fatayat NU, Nasyiatul Aisiyah, PD. Aisiyah, PC. Muslimat NU, dan Gabungan Wanita Gereja Kota Magelang.

b. Pendekatan informal

Pendekatan informal kepada pemilih perempuan di Kota Magelang dilakukan dengan kegiatan kehumasan yang menyasar pemilih perempuan secara individu. Jadi kelompok target ini adalah pemilih perempuan yang tidak menjadi anggota organisasi perempuan. KPU Kota Magelang tidak mengelompokkan pemilih perempuan ini secara spesifik sehingga dalam kegiatan kehumasan yang dilakukan oleh KPU Kota Magelang atau dengan melibatkan mitra KPU Kota Magelang menggunakan bahan sosialisasi yang sama kepada pemilih perempuan.

c. Pendekatan melalui media massa Pendekatan melalui media massa kepadà pemilih perempuan dilakukan oleh KPU Kota Magelang dengan kegiatan "media visit", yang dimaksudkan untuk menjaga hubungan dengan wakil-wakil dari media cetak atau elektronik yang ada di Kota Magelang. Kegiatan "media visit" dilakukan dengan beraudiensi dengan redaksi media cetak surat kabar harian Magelang Ekspres, Radar Kedu, Suara Merdeka perwakilan Kedu, Kedaulatan Rakyar perwakilan Magelang. Kegiatan "media visit" juga dilakukan dengan beraudiensi dengan media elektronik radio Magelang FM, CBS FM, UTM FM, Unima FM dan Tidar FM (KPU Kota Magelang, 2015: 16). Kelompok target dalam pendekatan melalui media massa adalah pemilih perempuan di Kota Magelang yang mengakses media cetak maupun elektronik tersebut. KPU Kota Magelang mengelompokkan pemilih perempuan ke dalam dua kelompok target, yaitu kelompok pemilih perempuan yang menjadi pembaca surat kabar dan pemilih perempuan pendengar radio. Media massa selain memberikan informasi tentang peristiwa-peristiwa, juga dapat dimanfaatkan untuk menyampaikan nilai-nilai utama yang dianut dalam masyarakat, termasuk nilai-nilai politik melalui ajakan yang dapat menumbuhkan keyakinan dan kesadaran politik (Mas`oed \& MacAndrews, 2011: 49).

d. Pendekatan melalui media jaringan

Pendekatan melalui media jaringan atau internet dilakukan 
Vol.05, No.01, April 2019

Doi: 10.24198/cosmogov.v2i2.xxxxx

oleh KPU Kota Magelang
melalui website KPU Kota
Magelang dengan alamat
http://www.kpud-
magelangkota.go.id/ dan email:
redaktur@kpud-
magelangkota.go.id.

Pemanfaatan media jaringan berupa website dan email resmi tersebut dimaksudkan untuk menyebarluaskan informasi kepemiluan dan sekaligus untuk menerima masukan dan aspirasi dari masyarakat. Penggunaan media jaringan tersebut tidak secara spesifik menyasar segmen pemilih tertentu, artinya semua orang dapat mengakses informasi kepemiluan dan tahapan Pilkada Kota Magelang tahun 2015 melalui media jaringan tersebut tanpa dibatasi ruang dan waktu.

Berdasarkan uraian di atas menunjukkan bahwa KPU Kota Magelang menggunakan empat pendekatan untuk menentukan kelompok target pemilih perempuan dalam Pilkada Kota Magelang tahum 2015. Melalui pendekatan formal dapat menentukan kelompok target pemilih perempuan secara tepat, yaitu pemilih perempuan anggota organisasi perempuan yang terdaftar di Kota Magelang. Disamping itu dengan pendekatan formal juga dapat mengelompokkan organisasi perempuan secara lebih spesifik berdasarkan profesi, agama, dan keanggotaan, sehingga akan mempermudah dalam mengimplementasikan kegiatan strategi sosialisasi politik kepada anggota organisasi perempuan yang disesuaikan dengan karakteristiknya.

Pendekatan informal kepada pemilih perempuan secara individu melalui kegiatan kehumasan juga dapat untuk menentukan kelompok target pemilih perempuan dalam Pilkada Kota Magelang tahun 2015. Pendekatan informal dengan sasaran kepada pemilih perempuan yang tídak menjadi anggota organisasi perempuan di Kota Magelang, seperti ibu rumah tangga, pedagang pasar atau pekerja dalam sektor perdagangan dan jasa. Mengingat banyak dan beragamnya jumlah pemilih perempuan yang menjadi target melalui pendekatan informal ini, maka KPU Kota Magelang bekerjasama dengan kelompok mitra KPU Kota Magelang dalam kegiatan sosialisasi politik.

Pendekatan melalui media massa kepada pemilih perempuan pada Pilkada Kota Magelang tahun 2015 juga dapat untuk memetakan kelompok target pemilih perempuan yang mengakses surat kabar atau radio lokal yang ada di Kota Magelang. Melalui kegiatan "media visit" kepada perwakilan media cetak ataupun elektronik dapat dirumuskan suatu rubrik atau acara yang 
Vol.05, No.01, April 2019

Doi: 10.24198/cosmogov.v2i2.xxxxx

disisipkan pada kolom atau program yang biasa mengulas masalah perempuan dari media cetak atau elektronik tersebut. Dengan cara tersebut maka perempuan pembaca surat kabar dan pemilih perempuan pendengar radio yang selama ini sudah ada eksistensinya akan mendapatkan informasi baru seputar kepemiluan dan Pilkada Kota Magelang tahun 2015. Sedangkan pendekatan melalui media jaringan atau internet yang dilakukan oleh KPU Kota Magelang tidak bisa secara khusus menyasar pemilih perempuan, karena informasi yang disampaikan merupakan informasi umum yang tidak memfokuskan kepada suatu kelompok sasaran pemilih tertentu.

\section{Jenis Strategi Sosialisasi Politik yang Diterapkan \\ KPU Kota Magelang dalam} melaksanakan kegiatan sosialisasi politik kepada pemilih perempuan pada Pilkada tahun 2015 menerapkan dua jenis strategi politik, yaitu strategi ofensif (menyerang) dan strategi defensif (bertahan) sebagaimana menurut Scroder (2010: 185).

a. Strategi Ofensif

Strategi ofensif yang digunakan oleh KPU Kota Magelang dalam sosialisasi politik dimaksudkan untuk meningkatkan jumlah pemilih perempuan dalam menggunakan hak pilihnya pada Pilkada tahun 2015. Melalui kegiatan-kegiatan yang familier sesuai dengan karakteristik dan aktifitas kelompok target pemilih perempuan, diharapkan materi sosialisasi politik dapat diterima dengan baik, sehingga dapat meningkatkan pengetahuan dan pemahaman tentang kepemiluan dan tahapan Pilkada tahun 2015. Kegiatan tersebut terdiri dari:

1) Kerjasama dengan Organisasi Perempuan

Upaya yang dilakukan oleh KPU Kota Magelang untuk mensosialisasikan Pemilu dan tahapan Pilkada tahun 2015 kepada pemilih perempuan melalui pendekatan formal difokuskan pada kegiatan yang berkaitan dengan aktifitas organisasi-organisasi perempuan yang ada di Kota Magelang. Untuk menyampaikan informasi kepemiluan dan tahapan Pilkada Kota Magelang tahun 2015 secara lebih tepat dan akurat sebagaimana menurut Scroder (2010: 328) dilakukan dengan menggolongkan organisasiorganisasi perempuan tersebut secara lebih spesifik berdasarkan profesi dan agama sebagai berikut:

Pertama, organisasi kekaryaan bidang perempuan, KPU Kota Magelang melakukan sosialisasi Pemilu dan tahapan Pilkada Kota Magelang tahun 2015 kepada organisasi kekaryaan bidang perempuan 
Vol.05, No.01, April 2019

Doi: 10.24198/cosmogov.v2i2.xxxxx

yang terdaftar di Kota Magelang yang terdiri dari Persit Kodim 0705 dan Bhayangkari Magelang Kota. Kegiatan sosialisasi kepada Persit Kodim 0705 dan Bhayangkari Magelang Kota dimaksudkan untuk memberikan pengetahuan tentang kepemilu dan tahapan Pilkada Kota Magelang kepada istri anggota TNI/Polri karena mereka mempunyai kepala keluarga yang secara profesionalisme tidak pernah bersentuhan dengan aktifitas politik.

Upaya yang dilakukan oleh KPU Kota Magelang dengan menggandeng organisasi kekaryaan bidang perempuan tersebut merupakan salah satu strategi untuk memperluas kelompok target, melalui kegiatan sosialisasi tentang kepemiluan dan tahapan Pilkada Kota Magelang tahun 2015 yang sebelumnya belum pernah dilakukan. Organisasi kekaryaan berdasarkan profesi baik yang dibentuk secara formal ataupun informal merupakan saluran penyampaian informasi yang paling jelas, dimana setiap anggota akan mengidentifikasikan diri dalam suatu organisasi tersebut dan menjadikan aktifitas-aktifitas organisasi, termasuk kegiatan sosialisasi kepemiluan dan tahapan Pilkada Kota Magelang tahun 2015 sebagai acuan (reference) dalam kehidupan politik sebagaimana menurut Mas`oed \& MacAndrews (2011: 48).

Kedua, organisasi keagamaan bidang perempuan, KPU Kota Magelang melakukan kerjasama dengan pengurus organisasi keagamaan bidang perempuan dalam melaksanakan agenda sosialisasi kepemiluan dan tahapan Pilkada Kota Magelang tahun 2015. Kerjasama dilakukan dengan melibatkan pengurus organisasi tersebut untuk melaksanakan sosialisasi kepada anggotanya. Pengurus yang ditunjuk mewakili organisasinya kemudian diberikan pembekalan materi kepemiluan dan tahapan Pilkada Kota Magelang tahun 2015 oleh KPU Kota Magelang. Selain itu KPU Kota Magelang juga memberikan bahan sosialisasi berupa brosur, leaflet, poster, dan sticker sebagai media untuk menyampaikan informasi kepemiluan dan tahapan Pilkada Kota Magelang tahun 2015 kepada anggotanya. Organisasi keagamaan bidang perempuan di Kota Magelang terdiri dari Fatayat NU, Nasyiatul Aisiyah, PD. Aisiyah, PC. Muslimat NU, dan Gabungan Wanita Gereja Kota Magelang.

Pengurus organisasi keagamaan bidang perempuan 
Vol.05, No.01, April 2019

Doi: 10.24198/cosmogov.v2i2.xxxxx

yang telah mengikuti kegiatan pembekalan berupa materi kepemiluan dan tahapan Pilkada Kota Magelang tahun 2015 kemudian melakukan sosialisasi kepada anggotanya. Pengurus organisasi tersebut diberikan keleluasaan dalam menjalankan agenda sosialisasi yang disesuaikan dengan kebiasaan yang berlaku dalam kegiatan rutinnya, seperti mengatur jadwal sosialisasi, tempat sosialisasi dan metode penyampaian informasi yang akan digunakan. Hal tersebut dilakukan agar para anggota organisasi keagamaan bidang perempuan merasa familier atau terbiasa dengan aktifitas yang selama ini sudah dijalankan dalam penyampaian informasi. Dalam organisasi keagamaan bidang perempuan setiàp anggota mempunyai ikatan berupa keyakinan yang sama dan sering berinteraksi secara rutin dan bersama-sama, sehingga akan mendorong mereka untuk menyesuaikan diri terhadap sikap atau tingkah laku yang dianut oleh organisasi tersebut (Rush \& Althoff, 2013: 27). Jadi dengan adanya sosialisasi kepemiluan dan tahapan Pilkada Kota Magelang tahun 2015 kepada organisasi keagamaan bidang perempuan juga akan mendorong para anggota untuk menyesuaikan diri terhadap nilai-nilai yang disampaikan dalam sosialisasi tersebut.

2) Membentuk Relawan Demokrasi Segmen Perempuan

Selain melalui pendekatan formal, upaya pendekatan kepada pemilih perempuan juga dilakukan secara informal melalui sosialisasi politik kepada pemilih perempuan yang tidak menjadi anggota organisasi perempuan, hal tersebut dilakukan dengan strategi membentuk relawan demokrasi segmen perempuan. Relawan demokrasi merupakan gerakan sosial yang dimaksudkan untuk meningkatkan partisipasi dan kualitas pemilih dalam menggunakan hak pilih dalam Pemilu. Relawan demokrasi melibatkan peranserta masyarakat yang seluas-luasnya dimana mereka ditempatkan sebagai pelopor demokrasi bagi komunitas atau lingkungannya (Bagian Bina Partisipasi Masyarakat Biro Teknis dan Hupmas KPU, 2015: 28). Relawan demokrasi segmen perempuan menjadi mitra KPU Kota Magelang dalam melaksanakan agenda sosialisasi politik yang diharapkan mampu menumbuhkan kesadaran terhadap pentingnya Pemilu termasuk Pilkada dalam 
Vol.05, No.01, April 2019

Doi: 10.24198/cosmogov.v2i2.xxxxx

kehidupan berbangsa dan bernegara.

Relawan demokrasi segmen perempuan dibentuk dengan cara seleksi yang meliputi seleksi administrasi dan wawancara. Seleksi administrasi dilakukan untuk memastikan bahwa calon relawan demokrasi merupakan warga Kota Magelang dan terdaftar sebagai pemilih dalam Pilkada Kota Magelang tahun 2015, sehingga benar-benar mengetahui kondisi wilayah dan masyarakat di lingkungannya. Kemudian seleksi wawancara dilakukan untuk mengetahui minat dan kemampuan dalam berkomunikasi, disamping itu seleksi wawancara juga untuk memastikan bahwa calon relawan demokrasi tidak menjadi anggota Partai Politik dalam 5 tahum terakhir maupun menjadi tim pemenangan pasangan calon dalâm Pilkada yang dibuktikan dengan kesediaan menandatangani surat pernyataan. Hasil seleksi relawan demokrasi segmen perempuan diumumkan secara terbuka oleh KPU Kota Magelang di papan pengumuman atau website untuk meminta masukan dan tanggapan masyarakat.

Berdasarkan hasil seleksi ditetapkan 17 orang perempuan yang menjadi relawan demokrasi segmen perempuan dengan wilayah kerja di 17 Kelurahan yang ada di Kota Magelang, artinya satu relawan demokrasi mempunyai wilayah kerja di satu Kelurahan. Relawan demokrasi segmen perempuan sebelum terjun ke masyarakat terlebih dahulu dibekali oleh KPU Kota Magelang dalam kegiatan "Bimbingan Teknis Relawan Demokrasi Segmen Perempuan" berupa materi kepemiluan dan tahapan Pilkada Kota Magelang tahun 2015, kode etik relawan demokrasi, dan teknik berkomunikasi dalam masyarakat. Selain itu KPU Kota Magelang juga memberikan dukungan administratif berupa formulir jadwal kegiatan, formulir laporan kegiatan dan bahan sosialisasi berupa brosur, leaflet, poster, dan sticker sebagai media untuk menyampaikan informasi kepemiluan dan tahapan Pilkada Kota Magelang tahun 2015 kepada pemilih perempuan.

Masa kerja relawan demokrasi dimulai sejak tahapan pemutakhiran data pemilih atau tanggal 1 Agustus 2015 sampai dengan tahapan penetapan pasangan calon Kepala Daerah terpilih tanggal 22 Desembr 2015. Dalam menjalankan tugasnya relawan demokrasi terikat dengan kode etik yaitu: 1). bersikap independen, 
Vol.05, No.01, April 2019

Doi: 10.24198/cosmogov.v2i2.xxxxx

imparsial, dan non partisan terhadap peserta Pilkada, 2). tidak melakukan tindakan kekerasan, 3). menghormati adat dan budaya setempat, 4). Tidak bersikap diskriminatif, 5). tidak menerima pemberian dalam bentuk apapun dari peserta Pilkada yang menunjukkan indikasi keberpihakan atau gratifikasi (KPU Kota Magelang, 2015: 18).

Relawan demokrasi segmen perempuan selain melakukan sosialisasi politik dengan mendatangi rumahrumah yang menjadi target sesuai dengan wilayah kerjanya, juga melakukan kegiatan sosialisasi politik secara bersama-sama di keramaian seperti kepada para pedagang pasar tradisional yang ada di Kota Magelang, yâng terdiri dari pasar Rejowinangun, pasar Kebonpolo, pasar Gotongroyong, dan pasar Cacaban. Pedagang pasar dipilíh sebagai kelompok target dengan pendekatan informal karena sebagian besar pedagang tradisional adalah perempuan dan mereka menghabiskan lebih banyak waktu untuk berjualan di pasar. Kehadiran relawan demokrasi segmen perempuan juga memberikan warna baru dalam kegiatan sosialisasi politik sebagai salah satu strategi yang diterapkan oleh KPU Kota
Magelang dalam Pilkada tahun 2015. Bahkan berdasarkan buku Laporan Pelaksanaan Sosialisasi Politik pada Pilkada Serentak Tahun 2015 di Jawa Tengah (KPU Jawa Tengah, 2015: 28) dari 21 Kabupaten/Kota yang melaksanakan Pilkada serentak di Jawa Tengah hanya KPU Kota Magelang yang membentuk relawan demokrasi khususnya segmen perempuan.

3) Pemanfaatan Media Massa Lokal Strategi

untuk mengakses kelompok target juga dilakukan melalui pendekatan media, agar KPU Kota Magelang dalam menyampaikan informasi kepemiluan dan tahapan Pilkada tahun 2015 dapat lebih luas menjangkau pemilih perempuan di Kota Magelang secara massif tanpa terkecuali. KPU Kota Magelang membangun hubungan dengan media cetak lokal dan media elektronik lokal yang ada di Kota Magelang melalui kegiatan sebagai berikut:

Pertama, Rubrik Tanya Jawab "Masyarakat Bertanya Pemilu, KPU Menjawab" di Surat Kabar Harian Lokal. Rubrik tanya jawab di surat kabar harian lokal (SKHL) Magelang Ekspres merupakan tindak lanjut dari kegiatan "media visit" yang dilakukan oleh KPU Kota Magelang. 
Vol.05, No.01, April 2019

Doi: 10.24198/cosmogov.v2i2.xxxxx

SKHL Magelang Ekspres dipilih sebagai media cetak untuk memuat rubrik tanya jawab tentang kepemiluan dan tahapan Pilkada tahun 2015 karena merupakan SKHL tertua dan mempunyai kapasitas edar paling tinggi di Kota Magelang. Berdasarkan company profile SKHL Magelang Ekspres merupakan SKHL pertama di Kota Magelang yang berdiri sejak tahun 2010, mulai tahun 2013 mempunyai kapasitas cetak sebanyak 18.000 eksemplar dengan wilayah edar di wilayah Magelang sebanyak 45,3\%, Temanggung 15,3\%, Wonosobo $17 \%$, Purworejo 14,6\%, dan Kebumen 7,8\%. Rubrik tanya jawab KPU Kota Magelang diampu oleh KPU Kota Magelang yang menjawab pertanyaan dari masyarakat seputar kepemiluan dan tahapan Pilkada Tahun 2015, pertanyaan tersebut dikirimkan ke redaksi SKHL Magelang Ekspres. Rubrik tanya jawab KPU Kota Magelang dengan masyarakat tersebut diberi judul "Masyarakat Bertanya Pemilu, KPU Menjawab", yang dimuat satu kali dalam seminggu, yaitu pada hari sabtu selama tahapan Pilkada Kota Magelang tahun 2015 berjalan. Rubrik tanya jawab "Masyarakat Bertanya Pemilu, KPU Menjawab" memang tidak secara spesifik membahas isu-isu yang berkaitan dengan pemilih perempuan, namun animo perempuan di Koa Magelang untuk mengirimkan pertanyaan seputar kepemiluan dan tahapan Pilkada tahun 2015 ke redaksi Magelang Ekspres cukup tinggi. Kedua, Dialog Interaktif "Perempuan Cerdas Berdemokrasi" di Lembaga Penyiaran Públik Lokal. Selain melalui media cetak lokal, KPU Kota Magelang juga melakukan kerjasama dengan lembaga penyiaran publik lokal (LPPL) radio Magelang FM. Kerjasama dituangkan dengan perjanjian kerja sama antara KPU Kota Magelang dengan Dinas Perhubungan, Komunikasi, dan Informatika Kota Magelang Nomor 53/KB/KPU-Kota $\mathrm{Mgl} / 2015$ dan Nomor 270/417/280/2015 tanggal 24 Maret 2015 tentang Sosialisasi Pemilu dan Penyelenggaraan Pilkada Kota Magelang Tahun 2015. Isi perjanjian tersebut berupa pelaksanaan sosialisasi oleh KPU Kota Magelang melalui kegiatan dialog interaktif yang difasilitasi oleh Dinas Perhubungan, Komunikasi, dan Informatika Kota Magelang melalui LPPL radio Magelang FM. Dialog interaktif dilaksanakan 1 kali dalam seminggu setiap hari rabu pukul 16.30 sampai dengan 
Vol.05, No.01, April 2019

Doi: 10.24198/cosmogov.v2i2.xxxxx

17.30 WIB selama tahapan Pilkada Kota Magelang tahun 2015 berlangsung. Adapun kelompok target sosialisasi politik dalam dialog interaktif tersebut terbagi menjadi dua segmen, yaitu untuk segmen pemilih secara umum dilaksanakan pada hari rabu minggu pertama dan ketiga dengan tema "Pemilu Bermartabat", sedangkan untuk segmen pemilih perempuan pada hari rabu minggu kedua dan keempat dengan tema "Perempuan Cerdas Berdemokrasi”. Pengisi acara dalam dialog interaktif tersebut adalah 5 orang anggota KPU Kota Magelang secara bergantian setiap ninggunya, dengan dipandu oleh pembawa acara dari LPPL radio Magelang FM.

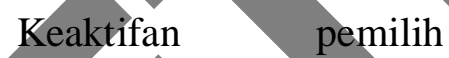
perempuan dalam diálog interaktif melalui radio dengan materi kepemiluan dan tahapan Pilkada Kota Magelang tahun 2015 menunjukkan bahwa adanya peningkatan kesadaran pemilih perempuan untuk ikut serta dalam aktifitas yang berkaitan dengan penanaman nilai-nilai politik. Kemudian kesadaran tersebut terus dibangun dan ditingkatkan oleh KPU Kota Magelang dengan menayangkan berbagai iklan layanan masyarakat (ILM) di seluruh radio yang ada di Kota Magelang seperti CBS FM, UTM FM, Unima FM dan Tidar FM. ILM juga dibuat dalam bentuk visual yang dimuat di SKHL yang ada di Kota Magelang seperti Magelang Ekspres, Radar Kedu, Suara Merdeka perwakilan Kedu, Kedaulatan Rakyar perwakilan Magelang. ILM tersebut berisi ajakan kepada pemilih untuk aktif dalam memastikan bahwa namanya sudah terdaftar sebagai pemilih di PPS, ajakan untuk mencermati visi dan misi pasangan calon Kepala Daerah, ajakan untuk ikut serta mendaftar sebagai penyelenggara Pemilu, dan ajakan untuk hadir dan menggunakan hak pilihnya di TPS pada hari pemungutan suara tanggal 9 Desember 2015.

b. Strategi Defensif

KPU Kota Magelang selain menggunakan strategi ofensif dengan tujuan untuk meningkatkan jumlah pemilih perempuan dalam menggunakan hak pilihnya pada Pilkada tahun 2015 melalui berbagai kegiatan-kegiatan baru, juga menggunakan strategi defensif yang dimaksudkan untuk mempertahankan pemilih perempuan yang selama ini sudah aktif dalam menggunakan hak pilihnya dan terlibat dalam rutinitas kegiatan sosialisasi politik bersama KPU Kota Magelang. Strategi defensif yang diterapkan oleh KPU 
Vol.05, No.01, April 2019

Doi: 10.24198/cosmogov.v2i2.xxxxx

Kota Magelang dilakukan dengan kegiatan-kegiatan sebagai berikut:

1) Kerjasama dengan Kader Penggerak PKK Kota Magelang

Upaya yang dilakukan oleh KPU Kota Magelang untuk "merawat" pemilih perempuan yang selama ini sudah aktif dalam menggunakan hak pilihnya dan terlibat dalam kegiatan sosialisasi politik bersama KPU Kota Magelang dilakukan dengan cara bekerjasama dengan kader penggerak Pemberdayaan dan Kesejahteraan Keluarga (PKK) Kota Magelang sampai ke tingkat Rukun Tetangga (RT). Kerjasama antara KPU Kota Magelang dengan penggerak PKK Kota Magelang dalam melaksanakan agenda sosialisasi politik dibidang kepemiluan kepada pemilih perempuan sudah dilaksanakan sejak tahapan Pemilu Anggota DPR, DPD, dan DPRD Tahun 2014 yang dituangkan dalam naskah perjanjian kerjasama nomor 02/KB/KPU-Kota Mg1/2012 dan 120/SKB/PKK-Kota/VI/2012 tanggal 23 Juni 2012 tentang Pelaksanaan Sosialisasi Pemilu Bagi Pemilih Perempuan. Melalui kerjasama tersebut kegiatan sosialisasi kepemiluan dimasukkan sebagai salah satu program kerja PKK Kota Magelang bidang Pembinaan Karakter dalam Keluarga
(Bidang 1) yang dijalankan sejak tahun 2012.

Kerjasama dalam

kegiatan sosialisasi kepemiluan anara KPU Kota Magelang dengan kader penggerak PKK Kota Magelang yang sudah terbangun sejak tahun 2012, semakin diintensifkan pada saat berjalannya tahapan Pilkada Kota Magelang tahun 2015, yaitu dengan menambah materi sosialisasi berupa tahapan Pilkada. Hal tersebut dimaksudkan untuk mempertahankan dan memperkuat pemahaman tentang materi kepemiluan dan tahapan Pilkada Kota Magelang bagi seluruh kader penggerak PKK di Kota Magelang. Kader penggerak PKK tingkat RT tersebut merupakan "ujung tombak" dalam melaksanakan kegiatan sosialisasi kepemiluan dan tahapan Pilkada Kota Magelang tahun 2015 kepada perempuan di lingkungannya yang tergabung dalam kelompok dasawisma. Kemudian anggota dasawisma yang telah mengikuti kegiatan sosialisasi tersebut juga diharapkan dapat menyampaikan informasi kepemiluan dan tahapan Pilkada Kota Magelang tahun 2015 tersebut kepada seluruh anggota keluarganya.

Informasi kepemiluan dan tahapan Pilkada Kota Magelang tahun 2015 juga 
Vol.05, No.01, April 2019

Doi: 10.24198/cosmogov.v2i2.xxxxx

disampaikan kepada seluruh anggota keluarga, baik kepada yang sudah ataupun yang belum memiliki hak pilih. Dengan begitu nilai-nilai politik tentang kepemiluan dan tahapan Pilkada mulai dikenalkan sejak dini, dimana keluarga merupakan struktur sosialisasi pertama yang dialamai oleh seseorang pada umumnya. Keluarga juga mempunyai pengaruh dalam pembentukan sikap terhadap wewenang kekuasaan, seperti dalam pembuatan keputusan bersama. Pengalaman berpartisipasi dalam pembuatan keputusan keluarga dapat meningkatkan perasaan kompetensi politik anggota keluarga, kecakapan interaksi nemberikan politik, dan membuatnya lebih mungkin berpartisipasi secara aktif dalam sistem politiknya sebagaimana menurut Maśoed \& MacAndrews (2011: 47). Kerjasama dengan kader penggerak PKK Kota Magelang selain dapat mempertahankan dan memperkuat pemahaman tentang materi kepemiluan dan tahapan Pilkada Kota Magelang tahun 2015 bagi seluruh kader penggerak PKK di Kota Magelang, juga bermanfaat bagi perempuan anggota Dasawiswa itu sendiri dalam mendapatkan informasi kepemiluan dan tahapan Pilkada Kota Magelang tahun 2015. Bahkan lebih jauh dari itu, nilai-nilai politik tentang kepemiluan dan tahapan Pilkada Kota Magelang tahun 2015 yang disampaikan oleh anggota Dasawisma kepada seluruh anggota keluarganya termasuk kepada anak-anak dapat memberikan manfaat terhadap pengenalan dan pembentukan nilai-nilai politik bagi generasi berikutnya. Pengenalan nilai-nilai politik tentang kepemiluan dan tahapan Pilkada Kota Magelang tahun 2015 akan tertanam lebih kuat kepada anak-anak apabila melihat praktek secara langsung, bagaimana orangtua atau lingkungan keluarganya yang sudah mempunyai hak pilih dalam berpartisipasi dalam Pilkada, seperti mendaftar sebagai pemilih, menonton debat pasangan calon Kepala Daerah di televisi, dan pada saat datang ke TPS untuk menggunakan hak pilihnya pada hari pemungutan suara.

2) Publikasi Informasi Kepemiluan melalui Website KPU Kota Magelang

Website KPU Kota Magelang merupakan media jaringan berbasis internet sebagai salah satu sarana bagi KPU Kota Magelang untuk menyampaikan informasi tentang kepemiluan. Website 
Vol.05, No.01, April 2019

Doi: 10.24198/cosmogov.v2i2.xxxxx

KPU Kota Magelang menjadi rujukan oleh pengguna internet untuk mendapatkan data dan informasi tentang kepemiluan, khususnya tentang pelaksanaan Pemilu dan Pilkada di tingkat Kota Magelang secara online. Secara garis besar informasi yang ditampilkan dalam website KPU Kota Magelang terbagi menjadi tiga bagian: pertama, berisi informasi tentang kepemiluan yang berisi sejarah KPU Kota Magelang, visi, dan misi KPU Kota Magelang, tugas dan kewenangan KPU Kota Magelang, pengertian Pemilu, sejarah Pemilu dan Pilkada, kedua, berisi tentang data berupa hasil penghitungan perolehan suara Pemilu anggota DPR, DPD, dan DPRD tingkat Kota Magelang, hasil penghitungan perolehan suara Pemilu Presiden dan Wakil Presiden tingkat Kota Magelang, hasil penghitungan suara Pilkada Kota Magelang, dan produk hukum KPU Kota Magelang, ketiga, berisi aktifitas terbaru terkait penyelenggaraan Pemilu dan Pilkada. KPU Kota Magelang telah mempromosikan website sebagai salah satu sarana untuk melakukan sosialisasi kepemiluan kepada masyarakat khususnya pengguna internet, hal tersebut dapat dilihat dari pencantuman alamat website KPU Kota Magelang http://www.kpud-

magelangkota.go.id/ ke dalam nomenklatur penulisan tata naskah dinas dan setiap bahan sosialisasi yang dibuat untuk disebarkan kepada masyarakat. Namun pemanfaatan website juga memiliki keterbatasan dalam hal interaksi dengan pengguna, penyampaian informasi hanya berlangsung satu arah. Meskipun KPU Kota Magelang telah mencantumkan alamat email resmi sebagai feedback dari pengguna, namun interaksi tersebut berlangsung tertutup antara administrator website dan pengguna saja.

Untuk menciptakan keterbukaan, komunikasi yang efektif dan interaktif, serta saling menguntungkan antara KPU Kota Magelang dengan masyarakat dalam pelaksanaan sosialisasi kepemiluan, seharusnya KPU Kota Magelang memanfaat media sosial. Penggunaan media sosial dalam melakukan sosialisasi kepemiluan dapat berpedoman pada Peraturan Menteri Pendayagunaan Aparatur Negara dan Reformasi Birokrasi Republik Indonesia Nomor 83 Tahun 2012 tentang Pedoman Pemanfaatan Media Sosial Instansi Pemerintah. Pemanfaatan media sosial oleh KPU Kota Magelang akan mendukung pelaksanaan 
Vol.05, No.01, April 2019

Doi: 10.24198/cosmogov.v2i2.xxxxx

sosialisasi kepemiluan secara efektif dan efisien, dimana seluruh agenda sosialisasi kepemiluan bisa dengan mudah dan murah untuk disampaikan kepada publik. Melalui media sosial berupa facebook atau twitter contohnya, jika seseorang telah meng-invite atau memfollow akun KPU Kota Magelang maka secara otomatis, segala sesuatu yang diposting oleh akun KPU Kota Magelang akan muncul di halaman home orang tersebut, dan biasanya orang tersebut akan membaca captions yang muncul di halaman facebook atau twitter mereka. Kemudian efek pesan berantai akan teraplikasi jika berita ataupun informasi kepemiluan yang diunggah oleh KPU Kota Magelang dianggap menarik netizen Penggunaan media sosial oleh KPU Kota Magelang dalam penyampaian informasi kepemiluan pada akhirnya akan membangun sebuah komunitas, sehingga akan terjalin komunikasi yang semakin intensif dan dapat bermanfaat untuk mempertahankan dan memperkuat pemahaman tentang materi kepemiluan.

Berdasarkan pemaparan di atas dapat dilihat bahwa KPU Kota Magelang menerapkan dua strategi, yaitu strategi ofensif dan defensif dalam melaksanakan kegiatan sosialisasi politik pada Pilkada tahun 2015. Strategi ofensif diterapkan melalui program-program baru yang selama ini belum pernah dilaksanakan pada kegiatan sosialisasi politik bagi pemilih perempuan pada Pilkada sebelumnya, dengan tujuan untuk meningkatkan jumlah pemilih perempuan dalam menggunakan hak pilihnya pada Pilkada. Sedangkan strategi defensif/diterapkan melalui program yang selama ini sudah berjalan dalam melaksanakan kegiatan sosialisasi politik kepada pemilih perempuan, dengan tujuan untuk mempertahankan jumlah pemilih perempuan yang selama ini sudah aktif menggunakan hak pilihnya dan ikut terlibat dalam rutinitas kegiatan sosialisasi politik bersama KPU Kota Magelang kepada pemilih perempuan.

\section{KESIMPULAN \\ KPU Kota Magelang sebelum} menerapkan strategi sosialisasi politik terlebih dahulu menentukan kelompok target agar dapat memetakan pemilih perempuan pada Pilkada Kota Magelang tahun 2015 secara spesifik. Kelompok target pemilih perempuan tersebut diakses melalui empat pendekatan yaitu: pendekatan formal, pendekatan informal, pendekatan melalui media massa, dan pendekatan melalui media jaringan. Dari empat pendekatan tersebut, yang dapat efektif digunakan untuk menentukan 
Vol.05, No.01, April 2019

Doi: $10.24198 /$ cosmogov.v2i2.xxxxx

kelompok target dalam pelaksanaan sosialisasi politik kepada pemilih perempuan pada Pilkada Kota Magelang tahun 2015 adalah tiga pendekatan saja, yaitu pendekatan formal, pendekatan informal, dan pendekatan melalui media massa.

KPU Kota Magelang menerapkan strategi ofensif dan defensif dalam melaksanakan kegiatan sosialisasi politik pada Pilkada Kota Magelang tahun 2015. Strategi ofensif diterapkan melalui program-program baru yang selama ini belum pernah dilaksanakan pada kegiatan sosialisasi pada Pilkada sebelumnya. Sedangkan strategi defensif diterapkan melalui program yang selama ini sudah berjalan dalam melaksanakan kegiatan sosialisasi politik kepada pemilih perempuan. Penerapan strategi ofensif lebih mendominasi dalam peningkatan partisipasi pemilih perempuan pada Pilkada Kota Magelang tahun 2015. Hal ini dapat dílihat dari beragamnya program baru yang dijalankan dan direspon positif oleh pemilih perempuan. Disamping itu, KPU Kota Magelang juga tidak mengabaikan strategi defensif, hal ini ditunjukkan dengan tetap terpeliharanya kerjasama dengan kader penggerak PKK Kota Magelang yang selama ini sudah terbangun dan ikut terlibat dalam rutinitas kegiatan sosialisasi politik bersama KPU Kota Magelang kepada pemilih perempuan.

\section{DAFTAR PUSTAKA}

\section{Buku}

ACE Electoral Knowledge Network. (2011). Encyclopedia Electoral Integrity: Guiding Principles of Electoral Integrity. ACEproject.

Almond, G. A., \& Jr, G. B. (1978). Comparative Politics, System, Process and Policy. Boston: Little Brown and company.

Beck, P. A. (1977). The Role of Agents in Political Socialization "Handbook of Political Socialization". (S. A. Renshon, Ed.) New York: The Free Press.

Bibler, S., Mohan, V., \& Ryan, K. (2014). Gender, Equality and EMB: Best Practice Guide. Washington: IFES.

Bryson, J. M. (2011). Strategic Planning for Public and Nonprofit Organizations: A Guide to Strengthening and Sustaining Organizational Achievement (Fourth Edition ed.). San Francisco: JosseyBass.

Budiardjo, M. (2015). Dasar-Dasar Ilmu Politik (Edisi Revisi). Jakarta: PT Gramedia Pustaka Utama.

Catt, H., Ellis, A., Maley, M., Wall, A., \& Wolf, P. (2014). Electoral Management Design: Revised Edition. Stockholm: International IDEA. 
Vol.05, No.01, April 2019

Doi: $10.24198 /$ cosmogov.v2i2.xxxxx

Jawa Tengah, K. (2015). Laporan Pelaksanaan Sosialisasi Politik pada Pilkada Serentak Tahun 2015 di Jawa Tengah. Semarang: KPU Jawa Tengah.

KPU. (2016). Partisipasi Pemilih Pilkada Serentak Tahun 2015. Jakarta: Komisi Pemilihan Umum.

Magelang, B. K. (2015). Statistik Daerah Kota Magelang 2015. Magelang: BPS Kota Magelang.

Magelang, K. K. (2016). Perjalanan Mewujudkan Pilkada Kota Magelang Tahun 2015 yang Bermartabat. Magelang: KPU Kota Magelang.

Mas`oed, M., \& MacAndrews, C. (2011). Perbandingan Sistem Politik. Yogyakarta: Gadjah Mada University Press.

Nurhaeni, I. D. (2009). Kebijakan Publik Pro Gender. Surakarta: UNS Press.

Rush, M., \& Althoff, P. (2013). Pengantar Sosiologi Politik. (K. Kartono, Trans.) Jakarta: Rajawali Pers.

Scroder, P. (2010). Strategi Politik (Edisi Cetakan Ketiga ed.). (A. Agoesman, Trans.) Jakarta: Friedrich-NaumannStiftung fuer die Freiheit.

Sihite, R. (2007). Perempuan, Kesetaraan, dan Keadilan: Suatu Tinjauan Berwawasan Gender. Jakarta: PT. Grafindo Persada.
Suparno, I., Ismunandar, K., \& Rochimah, T. N. (2005). Masih Dalam Posisi Pinggiran: Membaca Tingkat Partisipasi Politik Perempuan di Kota Surakarta. Yogyakarta: Pustaka Pelajar.

Jurnal

Brady, H. E., Verba, S., \& Schlozman, K. L. (1995). Beyond Ses: A Resource Model of Political Participation. American Political Science Review, 89, 271-294.

Dudley, R. L., \& Gitelson, A. R. (2002). Political Literacy, Civic Education, and Civic Engagement: A Return to Political Socialization? Applied Developmental Science, 6, 175-182.

Geys, B. (2006). Explaining Voter Turnout: a Review of Aggregate-Level Research. Electoral Studies, 25, 637663.

Hooghe, M. (2004). Political Socialization and the Future of Politics. Acta Politica, 39, 331-341.

Mar'iyah, C. (2001). Transisi Demokrasi dan Konsolidasi: Peran Negara dan Peluang Gerakan Perempuan. Jurnal Analisis Sosial, 15.

Pacheco, J. S. (2008). Political Socialization in Context: The Effect of Political 
Vol.05, No.01, April 2019

Doi: 10.24198/cosmogov.v2i2.xxxxx

Competition on Youth Voter Turnout. Polit Behav, 30, 415-436.

Sapiro, V. (2004). "Not your parents" political socializatio, Introduction for a new generation. Annual Review of Political Science, 1-23.

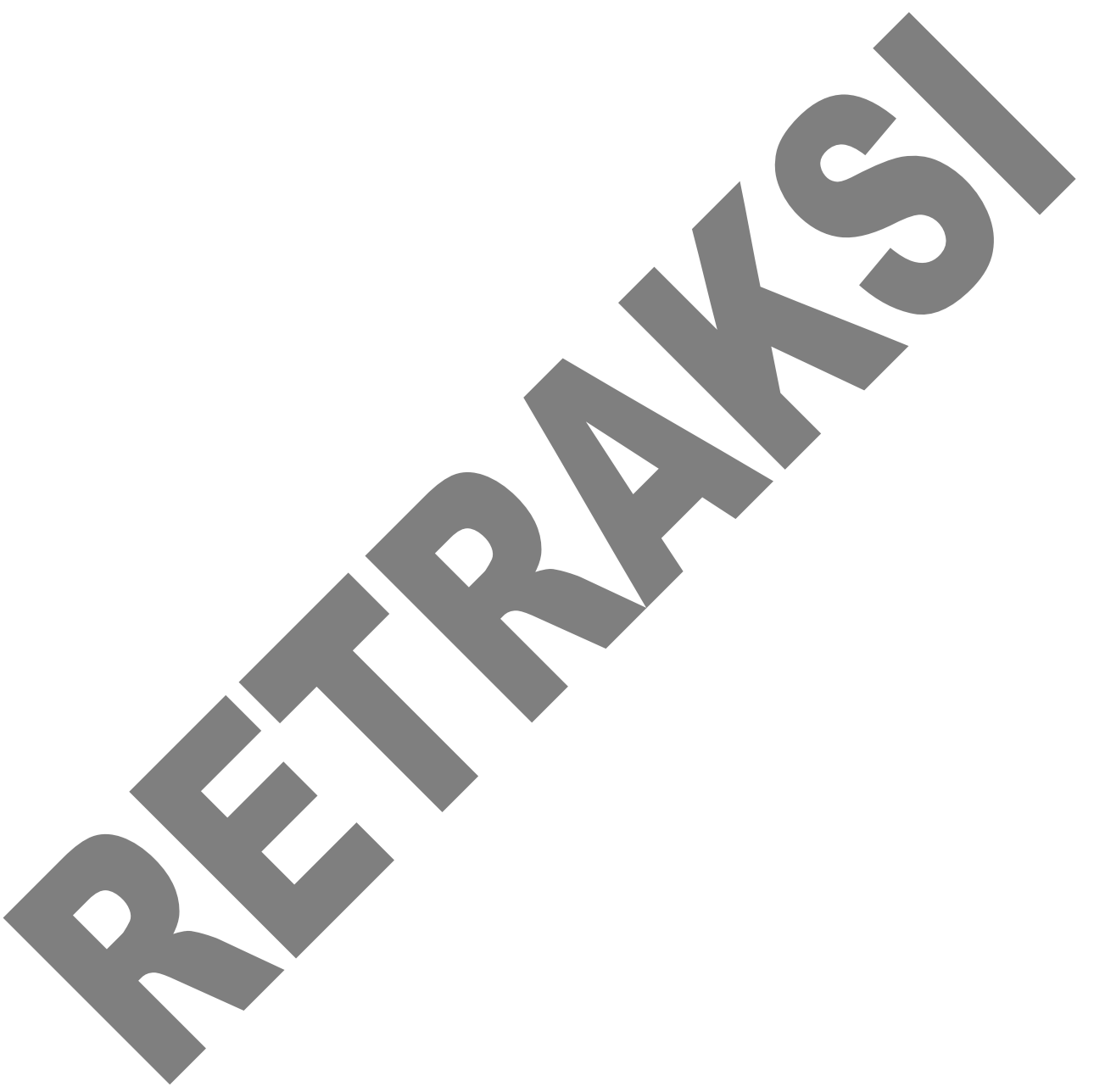

